\title{
Front Matter: Volume 10875
}

, "Front Matter: Volume 10875," Proc. SPIE 10875, Microfluidics, BioMEMS, and Medical Microsystems XVII, 1087501 (22 May 2019); doi:

$10.1117 / 12.2532080$

SPIE. Event: SPIE BiOS, 2019, San Francisco, California, United States 


\title{
PROGRESS IN BIOMEDICAL OPTICS AND IMAGING
}

\section{Microfluidics, BioMEMS, and Medical Microsystems XVII}

\author{
Bonnie L. Gray \\ Holger Becker \\ Editors
}

2-4 February 2019

San Francisco, California, United States

Sponsored by

SPIE

Cosponsored by

Microfluidic ChipShop GmBH (Germany)

The Ohio Center for Microfluidic Innovation (OCMI) at The University of Cincinnati (United States)

Published by

SPIE 
The papers in this volume were part of the technical conference cited on the cover and title page. Papers were selected and subject to review by the editors and conference program committee. Some conference presentations may not be available for publication. Additional papers and presentation recordings may be available online in the SPIE Digital Library at SPIEDigitalLibrary.org.

The papers reflect the work and thoughts of the authors and are published herein as submitted. The publisher is not responsible for the validity of the information or for any outcomes resulting from reliance thereon.

Please use the following format to cite material from these proceedings:

Author(s), "Title of Paper," in Microfluidics, BioMEMS, and Medical Microsystems XVII, edited by Bonnie L. Gray, Holger Becker, Proceedings of SPIE Vol. 10875 (SPIE, Bellingham, WA, 2019) Seven-digit Article CID Number.

ISSN: 1605-7422

ISSN: 2410-9045 (electronic)

ISBN: 9781510623927

ISBN: 9781510623934 (electronic)

Published by

SPIE

P.O. Box 10, Bellingham, Washington 98227-0010 USA

Telephone +1 3606763290 (Pacific Time) · Fax +1 3606471445

SPIE.org

Copyright (C) 2019, Society of Photo-Optical Instrumentation Engineers.

Copying of material in this book for internal or personal use, or for the internal or personal use of specific clients, beyond the fair use provisions granted by the U.S. Copyright Law is authorized by SPIE subject to payment of copying fees. The Transactional Reporting Service base fee for this volume is $\$ 18.00$ per article (or portion thereof), which should be paid directly to the Copyright Clearance Center (CCC), 222 Rosewood Drive, Danvers, MA 01923. Payment may also be made electronically through CCC Online at copyright.com. Other copying for republication, resale, advertising or promotion, or any form of systematic or multiple reproduction of any material in this book is prohibited except with permission in writing from the publisher. The CCC fee code is $1605-$ $7422 / 19 / \$ 18.00$.

Printed in the United States of America by Curran Associates, Inc., under license from SPIE.

Publication of record for individual papers is online in the SPIE Digital Library.

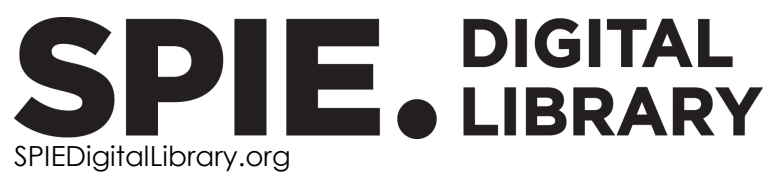

Paper Numbering: Proceedings of SPIE follow an e-First publication model. A unique citation identifier (CID) number is assigned to each article at the time of publication. Utilization of CIDs allows articles to be fully citable as soon as they are published online, and connects the same identifier to all online and print versions of the publication. SPIE uses a seven-digit CID article numbering system structured as follows:

- The first five digits correspond to the SPIE volume number.

- The last two digits indicate publication order within the volume using a Base 36 numbering system employing both numerals and letters. These two-number sets start with 00, 01, 02, 03, 04, $05,06,07,08,09,0 A, 0 B \ldots$ OZ, followed by 10-1Z, 20-2Z, etc. The CID Number appears on each page of the manuscript. 


\title{
Contents
}

\author{
vii Authors \\ ix Conference Committee
}

\section{MANUFACTURING I}

1087503 High-throughput thermal replication of transparent fused silica glass [10875-2]

1087504 Pure proteinaceous high-aspect-ratio microstructures made by femtosecond laser multiphoton cross-linking (Applications of 3D Printing Best Paper Award) [10875-3]

1087505 Structuring unbreakable and autoclavable hydrophobic barriers in paper via direct printing and mask-based photolithography [10875-4]

1087506 LIDE: high aspect ratio glass processing technology for the mass production of microfluidic devices for biomedical applications [10875-5]

\section{MANUFACTURING II}

1087507 Multifunctional microfluidic devices from tailored photopolymer formulations (Invited Paper) [10875-6]

1087508 Suspended liquid subtractive lithography: printing three dimensional channels directly into uncured polymeric matrices [10875-7]

10875 OA 3D printing of highly fluorinated methacrylates for the rapid prototyping of transparent and chemically resistant microfluidic devices [10875-9]

\section{MICROFLUIDIC DEVICES I}

10875 OC Automated laser-assisted synthesis of microarrays for infectious disease research (Invited Paper) [10875-11]

10875 OD Microfluidic mixing and jetting devices based on SU8 and glass for time-resolved molecular imaging experiments [10875-12]

10875 OE Confocal Raman thermometer for microfluidic devices [10875-13]

10875 OF Holographic imaging for tracking and phase retrieval in acoustophoresis platforms [10875-14] 
10875 OG Electrohydrodynamic cell concentration for biofabrication of agar-based 3D microtissues [10875-15]

\section{MICROFLUIDIC DEVICES II}

$108750 \mathrm{~J} \quad$ Dual dielectrophoresis controller and fluorescence analysis platform for capillary-driven microfluidics on a portable device [10875-18]

10875 OK Exact solution for laser-induced thermo-capillary force on a 3D microbubble in a liquid [10875-19]

$10875 \mathrm{OL} \quad$ An adaptive mesh refinement based simulation for pressure-deformability analysis of a circulating tumor cell [10875-20]

MANUFACTURING III

$1087500 \quad$ Zinc-oxide nanowires growth in-situ in microfluidic chamber [10875-23]

10875 OP Laser direct-writing to enable filtration in paper-based devices (Best Student Paper Award) [10875-24]

$108750 Q \quad$ Development of a robotic 3D bioprinting and microfluidic pumping system for tissue and organ engineering [10875-25]

MEDICAL DEVICES I

10875 OR Integrated microfluidic probes for cell manipulation and analysis (Invited Paper) [10875-26]

10875 OS Merging micro and nano: study of transport of gold nanoparticles inside a tumor microenvironment-on-a-chip [10875-27]

10875 OU 3D imaging in microfluidics: new holographic methods and devices [10875-29]

\section{OPTOFLUIDICS I}

10875 OV Breaking the trade-off between sensitivity and Q-factor for high-Q slot mode photonic crystal nanobeam cavity biosensors with optomechanical feedback [10875-30]

10875 OW Design and analysis of optical ring resonator for bio-sensing application [10875-31]

iv 
MEDICAL DEVICES II

$1087510 \quad$ Microfluidics for health monitoring applications (Invited Paper) [10875-35]

$1087511 \quad$ Microring resonator biosensing platform for sensitive detection of thrombin [10875-36]

OPTOFLUIDICS II

$1087516 \quad$ Optical fiber based light scattering detection in microfluidic droplets [10875-41]

$1087517 \quad$ High throughput optical analysis and sorting of cells and particles in microfluidic systems [10875-42]

\section{APPLICATIONS}

1087518 Studying the roundworm Caenorhabditis elegans using microfluidic chips (Invited Paper) [10875-43]

10875 1C A 3D printed centrifugal microfluidic platform for solid-phase-extraction and fluorescent detection of spilled oil in water [10875-47]

\section{POSTER SESSION}

$10875 \mathrm{lF} \quad$ Immuno-capture of cells in open microfluidics: microfluidic probes integrated with herringbone micro-mixers [10875-50]

$108751 G$ 3D printed micro-electro-fluidic probe (MeFP) for single cell electroporation [10875-51] 
Proc. of SPIE Vol. 10875 1087501-6

Downloaded From: https://www.spiedigitallibrary.org/conference-proceedings-of-spie on 26 Apr 2023 Terms of Use: https://www.spiedigitallibrary.org/terms-of-use 
Schneider, N., 03

Schreuder, Frederik, 11

Schröder, Sven, 16

Schulz-Ruhtenberg, Malte, 06

Schwilling, Patricia, 17

Serien, D., 04

Shvydkiv, Oksana, 16

Sones, Collin L., OP

Steiner, Mathias Bernhard, 0J

Stevens, Molly M., OP

Striegel, A., 03

Sugioka, K., 04

Sukumar, Pavithra, OR, IF

Suleman, Afzal, OS

Tan, Hua, OL

Thiele, Julian, 07

Thind, Sapanbir S., OS

Thomas, Michael R., OP

Tirapu-Azpiroz, Jaione, 0J

Tovar, Miguel, 16

Tsouka, A., OC

Tünnermann, Andreas, 16

Usman, Sadaf, $\mathrm{OQ}$

Valente, Karolina P., OS

Vassalli, M., OF

Vembadi, Abishek, OG

Villone, M., OU

Voss, Stephan, 08

Wang, Wanjun, $1 \mathrm{C}$

Wang, Yunxia, $1 \mathrm{C}$

Weigel, Niclas, 07

Wohlfeil, Shulin, 16

Worgull, M., 03

Xiang, Jiwen, $1 \mathrm{C}$

Xianyu, Yunlei, OP

Zhang, Yong, $1 \mathrm{C}$ 


\section{Conference Committee}

Symposium Chairs

James G. Fujimoto, Massachusetts Institute of Technology (United States)

R. Rox Anderson, Wellman Center for Photomedicine, Massachusetts General Hospital (United States) and Harvard Medical School (United States)

Symposium Co-chairs

Jennifer K. Barton, The University of Arizona (United States)

Wolfgang Drexler, Medical University of Vienna (Austria)

Program Track Chairs

Tuan Vo-Dinh, Fitzpatrick Institute for Photonics, Duke University (United States)

Anita Mahadevan-Jansen, Vanderbilt University (United States)

Conference Chairs

Bonnie L. Gray, Simon Fraser University (Canada)

Holger Becker, microfluidic ChipShop GmbH (Germany)

Conference Program Committee

Hatice Altug, Ecole Polytechnique Fédérale de Lausanne (Switzerland)

Brian W. Anthony, Massachusetts Institute of Technology (United States)

Jaione Tirapan Azpiroz, IBM Research - Brazil (Brazil)

Yolanda Fintschenko, FounderTraction (United States)

Bruce K. Gale, The University of Utah (United States)

Albert K. Henning, Aquarian Microsystems (United States)

Yu-Cheng Lin, National Cheng Kung University (Taiwan)

Yuehe Lin, Pacific Northwest National Laboratory (United States)

Ian Papautsky, University of Illinois at Chicago (United States)

Bastian E. Rapp, Albert-Ludwigs-Universität Freiburg (Germany)

Thomas Stieglitz, Albert-Ludwigs-Universität Freiburg (Germany)

Sindy Kam-Yan Tang, Stanford University (United States)

Hayden K. Taylor, University of California, Berkeley (United States)

Bernhard H. Weigl, Intellectual Ventures Management, LLC

(United States) 


\section{Session Chairs}

1 Manufacturing I

Holger Becker, microfluidic ChipShop GmbH (Germany)

Bonnie L. Gray, Simon Fraser University (Canada)

2 Manufacturing II

Bonnie L. Gray, Simon Fraser University (Canada)

3 Microfluidic Devices I

Bastian E. Rapp, Albert-Ludwigs-Universität Freiburg (Germany)

4 Microfluidic Devices II

Felix F. Loeffler, Max-Planck-Institut für Kolloid- und Grenzflächenforschung (Germany)

5 Manufacturing III

Julian Thiele, Leibniz-Institut für Polymerforschung Dresden e.V. (Germany)

6 Medical Devices I

Richard D. Oleschuk, Queen's University (Canada)

7 Optofluidics I

Mohammad A. Qasaimeh, New York University Abu Dhabi (United Arab Emirates)

8 Medical Devices II

Holger Becker, microfluidic ChipShop GmbH (Germany)

9 Optofluidics II

Martin Gijs, Ecole Polytechnique Fédérale de Lausanne (Switzerland)

10 Applications

Bonnie L. Gray, Simon Fraser University (Canada)

Holger Becker, microfluidic ChipShop GmbH (Germany) 